\title{
Cost-effectiveness analysis of cataract surgery with intraocular lens implantation: extracapsular cataract extraction versus phacoemulsification
}

\author{
Mohd Rizal Abdul Manaf', Syed Mohamed Aljunid', Faridah Hanom Annuar ${ }^{2}$, Chuah Kay Leong ${ }^{2}$, Normalina Mansor ${ }^{3}$
}

\begin{abstract}
Abstrak
Satu uji klinik acak buta tunggal untuk membandingkan efektifitas biaya teknik pembedahan antara ekstraksi katarak ekstrakapsular (ECCE) dan fakoemulsifikasi (PEA) telah dilakukan di Hospital Universiti Kebangsaan Malaysia (HUKM) antara Maret 2000 sampai Agustus 2001. Biaya yang dihitung pada kajian ini ialah biaya yang ditanggung oleh pihak nunah sakit, pasien, seita nunah tangga pada wakit sebelum pembedahan, satu minggu, dua bulan (untuk kedua-dua teknik) dan enam bulan (untuk ECCE saja). Penilaian efektifitas pembedahan katarak menggunakan 'Visual Function 14' (VF-14) yaitu kualitas hidup mengenai fungsi penglihatan. Hasil analisis biaya masing-masing 50 subjek pada ECCE dan PEA menunjukkan bahwa rata-rata biaya pembedahan untuk satu kasus ECCE setelah enam bulan pembedahan sebesar USD 458 ( \pm USD 72) dan bagi PEA sebesar USD 528 ( \pm USD 125). Skor VF-14 meningkat dengan signifikan setelah seminggu, dua bulan dan enam bulan pasca pembedahan dibandingkan sengan skor sebelum pembedahan bagi kedua teknik $(p<0,001)$. Namun, tidak terdapat perbedaan yang signifikan antara teknik pembedahan ECCE dan PEA $(p=0.225)$. Hasil kajian menunjukkan bahwa biaya dengan teknik pembedahan ECCE lebih efektif dibandingkan dengan PEA yaitu biaya per peningkatan satu init kualitas kehidupan (VF-J4) untuk ECCE adalain USD 14 dibandingkan dengan PEA sebesar USD 20. (Med J Indones 2007; 16:25-31)
\end{abstract}

\begin{abstract}
A randomized single blinded clinical trial to compare the cost-effectiveness of cataract surgery between extracapsular cataract extraction (ECCE) and phacoemulsification (PEA) was conducted at Hospital Universiti Kebangsaan Malaysia (HUKM) from March 2000 until August 2001. The cost of a cataract surgery incurred by hospital, patients and households were calculated preoperatively, one week. two months (for both techniques) and six months (for ECCE only). Effectiveness of cataract surgery was assessed using Visual Function $14(V F-14)$, quality of life measurement specifically for vision. The cost analysis results from each 50 subjects of ECCE and PEA group showed that average cost for one ECCE after six months post-operation is USD 458 ( \pm USD 72) and for PEA is USD 528 ( \pm USD 125). VF-14 score showed a significant increased after a week, wo months and six months post-operation compared to the score before operation for both techiniques $(p<0.001)$. However, there was no significant difference between them $(p=0.225)$. This study indicated that ECCE is more cost effective compared to PEA with cost per one unit increnent of VF-14 score of USD 14 compared to USD 20 for PEA. (Med J Indones 2007; 16:25-31)
\end{abstract}

Keywords: cataract, cost-effectiveness, extracapsular cataract extraction, phacoemulsification, visual function 14

Cataract is the leading cause of blindness in Malaysia and worldwide, affecting more than 20 million individuals. ${ }^{1}$ Global number of people with visual impairment. was in excess of 161 million, of whom about 37 million were blind. ${ }^{2}$ There are two main cataract surgery

\footnotetext{
'Department of Conmunity Health, Faculty of Medicine, Universiti Kebangsaan Malaysia, Kuala Lumpur, Malaysia

${ }^{2}$ Department of Ophthalmology, Faculty of Medicine,

Universiti Kebangsaan Malaysia, Kuala Lumpur, Malaysia

'Department of Ophthalmology, Faculty of Medicine. Universiti Teknologi Mara, Kuala Lumpur, Malaysia
}

techniques performed in Hospital Universiti Kebangsaan Malaysia (HUKM), i.e. phacoemulsification (PEA) which is relatively new and the conventional method of extracapsular cataract extraction (ECCE). Compared with ECCE, PEA requires a smaller corneal incision but needs special equipment, additional consumables ${ }^{3}$ and more expensive. ${ }^{4}$ Among the advantages of PEA are faster visual recovery, lower incidence of postoperative astigmatism, early stabilization of refraction and sustained intraocular pressure control during operation. ${ }^{5.6}$ A systematic review by Snellingen et al. revealed that PEA gives a better visual outcome than extracapsular extraction with sutures. ${ }^{7}$ Despite these 
advances, cataract continues to be a leading publichealth issue that will grow in importance as the population increases and life expectancy is extended worldwide. $^{8}$

Several instrument have been developed for measuring functional capacity related to impaired vision in patients with cataracts. ${ }^{9}$ Among them, the Visual Function 14 (VF-14), has been shown to be reliable and valid "and quite responsive to clinical change after cataract surgery. ${ }^{10}$

Despite the large number of cataract extractions performed in Malaysia, very little is known about the costs or variation in costs between ECCE and PEA. Further more, there is very little information about the effectiveness of the cataract surgery performed. The objectives of this study were to analyze and compare the cost of cataract surgery by ECCE and PEA in HUKM, measure the quality of life as the outcome and perform cost effectiveness analysis comparing ECCE and PEA.

\section{METHODS}

This study covered a period of 18 months from March 2000 to August 2001. During the study period, there were 1,396 cataract patients who were referred to HUKM by public and private health care facilities. Out of this number, 100 patients who fulfilled the inclusion and exclusion criteria (Table 1) were randomly selected and allocated into two groups; 50 in ECCE and 50 in PEA group using computer generated randomize table. The patients underwent five visits during the study and they were interviewed by the researcher in the ophthalmology clinic and ward. In the first visit they were examined and recruited into the study. Patients were admitted in the second visit and operation was carried out. The third and fourth visit was carried out one week and two months after they were discharged. Six months after the cataract surgery, patients visited the hospital again for the final follow-up. In each visit and admission, costs and quality of life data were recorded except costing for PEA patients at six months post-operation. This data is excluded because PEA patients did not require follow-up at six months but they came just for the of quality of life assessment.

This study was approved by the Intensification of Research in Priority Areas Research Committee, Ministry of Science, Technology and Innovation, Malaysia.
Table 1. Inclusion and exclusion criteria

Inclusion criteria

1. Patients aged above 44 years old

2. Patients who had best corrected visual acuity of $6 / 60$ or better with symptoms due to cataract such as blurred vision, glare, altered color sensation and progressive myopia

3. Patients who underwent first cataract surgery

Exclusion criteria

A) General factors;

1. Patients who are difficult to assess due to mental or physical handicap such as senile dementia, frailty or deformity

2. Patients who have past history of eyc injury

3. Patients with cerebral vascular accident causing significant visual loss

4. Patients undergoing major surgery within the study period

5. Anxious patients who require general anesthesia

B) Ocular factors:

1. Any corneal opacity encroaching the central zone of $3 \mathrm{~mm}$ diameter

2. Other causes of media opacity such as vitreous hemorrhage

3. Difficult papillary dilatation

4. Glaucoma

5. Maculopathy of any pathology

\section{Assessment of costs}

The costing data for cataract surgery was calculated from a sub-sample of 60 patients out of the total number of 100 patients selected. Costs incurred by the hospital (provider) and by patients (including household's costs) were imputed in the study. Provider costs were further classified into capital and recurrent costs. These costs were based on the financial year 1999.

Capital costs for provider included building, furniture and equipment costs. All capital costs were discounted at the rate of $5 \%$ per annum. The useful life of building was assumed to be 20 years while life span of furniture was five years. Life span of equipment was based on the article by Asimakis et al. "All equipment that cost above RM 500 were considered as capital. The total capital costs were further divided by the total number of patients using the facilities to obtain the unit cost. Vehicle cost was not included because there was no transportation used by the hospital for cataract surgery.

Recurrent costs, included in this study were personnel, consumables, laboratory investigations, drugs, administration. 
utility and maintenance of equipment. Personnel costs were based on total emolument and time spent for each activity by the surgeons, doctors, nurses and attendants. Emolument of each category of personnel includes salary, allowances, overtime and bonuses received in the year 1999. Purchasing price of the consumables were used as the costs. Laboratory investigations costs were calculated based on the charges to patients by the hospital.

Costs for drugs included eye drops and other medications given in the ward, and after patient was discharged one weck, two months, and six months post-operation. Administration costs were an approximation, we assumed one third of the total administration personnel time was allocated to outpatients and two third for inpatients. These costs were further divided by the total number of HUKM outpatients and inpatients for the year 1999, in order to get unit cost for administration. Utility and maintenance costs were calculated based on floor space of each clinic, ward and operation theatre used in the cataract surgery activities. Training expenses in both ECCE and PEA techniques was not included.

Patient costs included in this study were clinic fees, transportation, waiting time, other eye treatment expenses, co-morbidity treatment, intraocular lens implant, ward charges, cost of extra visits and household costs. Clinic fees were based on the charges by the hospital for each clinic visit. Transportation cost for patients and their relatives included the journey to and from the hospital. Waiting time for patient was calculated based on total time spent waiting in the ophthalmology clinic before seeing the doctor. The time spent was converted into cost by multiplying the number of minutes spent during the visit with patient's income in minute (monthly income divide by 10,560 : this figure is derived by multiplying the 22 working days per month by 8 working hours per day -22 days $X 8$ hours X 60 minutes). No cost was considered for unemployed patients. Cost of other eye treatment was cost incurred by patients in treating the eye problems one year before the cataract surgery. Cost of comorbidity treatment considered in this study was calculated for a period of one year. The co-morbidities were mainly hypertension and diabetes mellitus.

Intraocular lens implant and ward charges were based on the charges by the hospital. Patients with abnormal laboratory results and complications during and after operation were required to come for extra visits. Cost of extra visits incurred by patients included transportation cost, waiting time, additional laboratory costs and cost incurred by those who accompanied the patient during the extra visits. The household cost is the cost of time spent by a spouse or relative in the clinic while accompanying the patient. This is based on income of the spouse or relative.

Indirect cost due to less of income for a working patient after discharge was not included in this study. This cost is difficult to assess because patients may continue to work despite medical certification of being unfit for duty especialiy those who are self-employed. Assessment of intangible costs, such as pain, emotional well-being and ability to interact with and support others were not included in the cost analysis.

The total cost of cataract surgery is calculated by adding up the total hospital costs and patient costs, subtracting the clinic and ward charges. The clinic and ward charges are excluded to avoid double counting since they are also calculated as hospital costs.

\section{Assessment of effectiveness}

Effectiveness of cataract surgery was assessed by quality of life score using Visual Function 14 (VF-14) questionnaire. It is an instrument designed to provide a specific measure of visual functioning in cataract patients. ' It contains 14 items that include a broad spectrum of vision dependent activities performed in everyday life that may be affected by cataract. ${ }^{12}$

Patients were asked whether, even with their most recent glasses, they had any difficulty in performing the task. The responses allowed were 'yes', 'no', or 'do not do that activity for reasons unrelated to vision'. For each activity in which patients responded to as 'yes', they were asked on how much difficulty they currently had with that activity - 'a little', 'a moderate amount', 'a great deal', or 'unable to do' because of their vision. The score was based on all applicable items and the amount of reported difficulty experienced in performing those activities. An item was not included in the scoring if patients did not do that activity for a reason other than their vision. No minimum number of applicable items was required. The final score produced by this index ranges from 0 (unable to do all applicable activities because of vision) and a maximum of 100 (able to do all applicable items without difficulty). 


\section{Cost-effectiveness analysis}

In cost-effectiveness analysis, we measured cost per one unit increment of VF-14 score. The formula for calculation is the total cost divide by the different in the VF-14 score between pre and six months postoperation. The surgical technique which had less cost per one unit increment of $\mathrm{VF}-14$ is considered more cost effective compared to the other.

\section{Longitudinal follow-up}

All patients turned up for the follow-up at one week and two months visits. However after six months follow-up, 93 patients came for the visit ( 47 for ECCE and 46 for PEA). Despite attempts to contact them, the five patients did not turn up for the last follow-up and two patients were unable to be contacted due to change in address.

\section{Data analysis}

Data was analyzed using Statistical Package for Social Science (SPSS) program version 10.0. Chi-square was used to determine any difference in patients' characteristics between ECCE and PEA. In terms of costs, t-test was used to determine the difference in the average cost between the two types of cataract surgery. General Linear Model (GLM) repeated measure was used to compare the VF-14 score between ECCE and PEA as well as difference within the group at four different times.

\section{Sensitivity analysis}

We performed sensitivity analysis by using different discount rates and different rate of PEA operation done in the hospital. We used $0 \%$ and $10 \%$ discount rates in sensitivity analysis to assess any changes in the cost effectiveness analysis. In 1999, the PEA operation rate in HUKM was $22.4 \%$. In sensitivity analysis, the cost-effectiveness ratio was compared when PEA rate is increased to $50 \%$.

\section{RESULTS}

\section{Characteristics of patients}

The socio-demographic characteristics, presence of co-morbidities, or prevalence of seeking eye treatment before the cataract surgery were homogenous in both the ECCE and PEA groups (Table 2).
Table 2. Some characteristics of subjects

\begin{tabular}{|c|c|c|c|c|}
\hline \multirow{2}{*}{ Characteristics } & \multicolumn{2}{|c|}{$\mathrm{ECCE}$} & \multicolumn{2}{|c|}{ PEA } \\
\hline & $n$ & $\%$ & n & $\%$ \\
\hline \multicolumn{5}{|l|}{ Sex } \\
\hline Males & 22 & 44.0 & 21 & 42.0 \\
\hline Females & 28 & 56.0 & 29 & 58.0 \\
\hline \multicolumn{5}{|l|}{ Ethnic } \\
\hline Malay & 24 & 48.0 & 23 & 46.0 \\
\hline Chinese & 25 & 50.0 & 26 & 52.0 \\
\hline Indian & 1 & 2.0 & 1 & 2.0 \\
\hline \multicolumn{5}{|l|}{ Age (years) } \\
\hline $45-54$ & 6 & 12.0 & 8 & 16.0 \\
\hline $55-64$ & 16 & 32.0 & 19 & 38.0 \\
\hline $65-74$ & 22 & 44.0 & 21 & 42.0 \\
\hline 75 and above & 6 & 12.0 & 2 & 4.0 \\
\hline \multicolumn{5}{|l|}{ Level of education } \\
\hline No Schooling & 18 & 32.0 & 18 & 36.0 \\
\hline Primary & 26 & 52.0 & 23 & 46.0 \\
\hline Secondary \& Tertiary & 6 & 12.0 & 9 & 18.0 \\
\hline \multicolumn{5}{|l|}{ Occupation } \\
\hline Unemployed / Housewife & 34 & 68.0 & 29 & 58.0 \\
\hline Pensioner & 7 & 14.0 & 11 & 22.0 \\
\hline Working & 9 & 18.0 & 10 & 20.0 \\
\hline \multicolumn{5}{|l|}{ Co-morbidity } \\
\hline Yes & 32 & 64.0 & 28 & 56.0 \\
\hline No & 18 & 36.0 & 22 & 44.0 \\
\hline \multicolumn{5}{|l|}{$\begin{array}{l}\text { Eye treatment before } \\
\text { cataract surgery }\end{array}$} \\
\hline Yes & 26 & 52.0 & 32 & 64.0 \\
\hline No & 24 & 48.0 & 18 & 36.0 \\
\hline
\end{tabular}

\section{Cataract surgery cost}

Cost profiles of both ECCE and PEA up to six months post-operation are shown in Table 3. Cost of equipment, personnel, consumables, and drugs differs significantly between the two groups of patients. Even though PEA has lower personnel and drugs cost, the cost of consumables and equipment is very much higher than ECCE. The equipment for PEA is nearly three times higher than those used in ECCE. The ECCE drugs cost is about five times higher than PEA group. Cost of intraocular lens implant is the major expense incurred by patients in both groups. It represents nearly half of the patient's cost in both groups. PEA requires patients to use a more expensive lens (USD 8 more) than those in the ECCE group.

In terms of cost incurred by the hospital and by patients, it was found that patients had to bear a higher portion of the total cost: $60.9 \%$ in ECCE and $54.6 \%$ in PEA. The average cost of cataract surgery using PEA is about $15.3 \%$ higher than ECCE. The hospital costs for PEA exceeded ECCE by $26.9 \%$. 
Table 3. Cost profiles of ECCE and PEA 6 months post-operation ii USD

\begin{tabular}{|c|c|c|c|}
\hline Inputs & $\frac{\text { ECCE }}{\text { Mean (SD) }}$ & $\frac{\text { PEA }}{\text { Mean (SD.) }}$ & $p$ value \\
\hline \multicolumn{4}{|l|}{ A) Hospital costs } \\
\hline $\begin{array}{l}\text { Capital costs } \\
\text { Building } \\
\text { Furniture } \\
\text { Equipment }\end{array}$ & $\begin{array}{c}16.81(2.10) \\
8.54(0.05) \\
41.57(0.35)\end{array}$ & $\begin{array}{c}15.49(1.00) \\
8.52(0.02) \\
114.45(0.53)\end{array}$ & $\begin{array}{l}0.096 \\
0.096 \\
0.000\end{array}$ \\
\hline $\begin{array}{l}\text { Recurrent costs } \\
\text { Personnel } \\
\text { Consumables } \\
\text { Laboratories } \\
\text { Drugs } \\
\text { Administration } \\
\text { Utility and maintenance }\end{array}$ & $\begin{array}{c}33.73(3.02) \\
33.83(0.09) \\
43.47(14.21) \\
15.69(3.36) \\
8.87(0.87) \\
13.11(1.64)\end{array}$ & $\begin{array}{c}23.29(3.00) \\
51.45(0.11) \\
37.16(9.83) \\
2.94(1.04) \\
8.21(0.53) \\
12.08(0.78)\end{array}$ & $\begin{array}{l}0.000 \\
0.000 \\
0.059 \\
0.000 \\
0.096 \\
0.096\end{array}$ \\
\hline Total hospital costs & $215.61(15.37)$ & $273.56(11.49)$ & $0.000^{*}$ \\
\hline $\begin{array}{l}\text { B) Patient costs } \\
\text { Clinic fees } \\
\text { Transportation } \\
\text { Waiting time } \\
\text { Eye treatment } \\
\text { Co-morbidity } \\
\text { Lens (fixed price) } \\
\text { Ward charges } \\
\text { Extra visit } \\
\text { Household }\end{array}$ & $\begin{array}{c}3.69(5.06) \\
16.63(11.16) \\
21.30(32.67) \\
1.47(3.49) \\
14.38(28.12) \\
126.32 \\
32.95(31.43) \\
2.44(12.93) \\
59.47(47.65)\end{array}$ & $\begin{array}{c}4.04(4.73) \\
11.99(7.56) \\
39.77(80.48) \\
4.21(11.85) \\
14.48(27.42) \\
134.21 \\
29.68(27.84) \\
3.16(6.97) \\
46.43(57.32)\end{array}$ & $\begin{array}{l}0.901 \\
0.750 \\
0.207 \\
0.230 \\
0.923 \\
\\
0.538 \\
0.791 \\
0.086\end{array}$ \\
\hline Total patient costs & $278.65(68.27)$ & $287.98(112.36)$ & 0.901 \\
\hline Total cataract surgery costs & $457.62(72.28)$ & $527.82(124.53)$ & 0.027 \\
\hline
\end{tabular}

\section{VF-14 score}

There was a significant increased in VF-14 scores from the score taken prior to operation, one week, two months and six months after operation in both techniques (GLM within subject effects, $p<0.001$ ). The VF-14 scores for ECCE and PEA were increased by $51.1 \%$ and $39.5 \%$ respectively. However there was no difference in the score when compared between ECCE and PEA as shown in Table 4 (GLM between subject effects, $\mathrm{p}=0.225$ ).

Table 4, Mean score of Visual Function 14 (VF-14)

\begin{tabular}{|c|c|c|c|c|}
\hline Time & \multicolumn{2}{|c|}{ ECCE } & \multicolumn{2}{|c|}{ PEA } \\
\hline Interviewed & Mean & $\mathrm{SD}$ & Mean & SD \\
\hline Before Operation & 64.05 & 19.79 & 68.37 & 18.68 \\
\hline $\begin{array}{l}\text { One Week } \\
\text { Post-Operation }\end{array}$ & 89.21 & 11.42 & 92.10 & 8.51 \\
\hline $\begin{array}{l}\text { Two Months } \\
\text { Post-Operation }\end{array}$ & 93.43 & 6.97 & 95.34 & 6.92 \\
\hline $\begin{array}{l}\text { Six Months } \\
\text { Post-Operation }\end{array}$ & 96.76 & 6.02 & 95.40 & 6.14 \\
\hline
\end{tabular}

\section{Cost-effectiveness analysis}

Result from cost-effectiveness analysis has shown that ECCE technique is more cost-effective compared to PEA based on the cost per one unit increment of VF-14 score after six months (Table 5). The cost per one increment of VF-14 for ECCE is USD 14 where as for PEA is USD 20.

Table 5. Cost (USD) per one increment of VF-14 after 6 months

\begin{tabular}{lcc}
\hline & ECCE & PEA \\
Total cost of operation & 457.62 & 527.82 \\
VF-14 score difference & 32.71 & 27.03 \\
Cost per one increment of & 13.99 & 19.53 \\
VF-14 score & &
\end{tabular}

\section{Sensitivity analysis}

Sensitivity analysis of the results showed that the cost per one unit increment of VF-14 of PEA will drop to USD 18 , if the PEA is carried out in $50 \%$ of patients requiring cataract surgery in the hospital, while the ECCE rate remain constant. At this situation, ECCE 
still more cest-effective but the difference is much lesser. However by keeping the current rate of ECCE and PEA, and using $0 \%$ and $10 \%$ discount rates, the difference between the two methods remains favoring ECCE.

\section{DISSCUSSION}

This randomized single blinded study showed that cost of PEA is significantly higher than ECCE. This finding is similar to a study done by Loo et al. which found that PEA with intraocular lens implant cost is more expensive than ECCE with intraocular lens implant. ${ }^{13}$. Theoretically, there are a number of advantages in carrying out PEA. The personnel and drugs costs are less because PEA can be done in relatively shorter operation time than ECCE. In this study it was found that the average operation time for PEA is 21.8 minutes compared to 43.2 minutes for ECCE. The PEA technique is also less invasive where a smaller incision is required compared to ECCE. Through this small incision, the lens nucleus is phacoemulsified using a low flow/high vacuum machine. In ECCE, the lens nucleus was expressed using bimanual technique. However Minassion et al. found that in the UK setting, the average cost of cataract extraction by PEA was similar to the average cost of ECCE i.e $\$ 332.89$ (USD 596) compared to 335.07 (USD 600). ${ }^{3}$

The cost of the special equipment is the major disadvantage of PEA technique. ${ }^{3}$ The average cost is higher when the volume of operation carried out using the technique is small. This is because the number of surgeons trained using PEA technique is small and hence this type of operation is not being carried out that frequently compared to ECCE.

The difference in drug treatment cost is caused by the difference in the anti-inflammatory eye drops used by both groups of patients. For PEA patients, the ophthalmologist preferred to use Dexamethasone $0.1 \%$, Neomycin $3500 \mathrm{iu} / \mathrm{ml} \&$ Polymixin B 6000 $\mathrm{iu} / \mathrm{ml}$ eye drop (Maxitrol) which cost USD 0.6 per bottle whereas for ECCE patient, the ophthalmologist used Betamethasone Sodium Phosphate $0.1 \%$ \& Neomycin Sulfate $0.5 \%$ eye drop (Betnesol $N$ ) that cost USD 3 per bottle. If Maxitrol eye drop usage was standardized in both techniques, ECCE would be much more cheaper than PEA.

The result of this study concurs with study done by Asimakis et al, ${ }^{11}$ where they found that the hospital costs for FCCE without any complication was AUD $1,000.85$ (USD 527) and for PEA was AUD 1,231.00 (USD 648). However the difference in hospital costs in our study is slightly higher than those found by Asimakis et al. "In our study, the difference is $26.9 \%$ whereas in Asimakis's study the difference was $23.0 \%$.

Another study which was conducted in Sweden has shown that the average cost for a cataract surgery performed at the eye clinic was 5,052 SEK (USD 492.) ${ }^{14}$ The majority of their cases $(90 \%)$ were performed using the PEA technique. The average cost of this type of cataract surgery was found to be more costly compared to our finding. This was due to the high cost for personnel, which was found to be 1,449 SEK (USD 141) (28.7\%) of the total cost of cataract surgery performed. This is extremely high compared with that found in our study which was USD 27 $(9.9 \%)$

This study has shown that cataract surgery is effective based on the vision related quality of life (VF-14) that increased significantly before and after six months operation. VF-14 is a better measure of visual function in real situation compared to visual acuity since it takes daily activities of the patient into account and includes binocular vision, something which is neither measured nor easy to estimate using the Snellen chart for determining visual acuity. ${ }^{15}$

This study has also indicated that ECCE technique is more cost effective compared to PEA after six months post-operation. This result is further enhanced by sensitivity analysis which revealed the same finding. However the results should be interpreted taking into account the limitations of the study. The main limitation is the time-frame where cases were followed-up just six months after operation. PEA will not require any more extra visit after two months. Patients on ECCE have to undergo two more visits after six months to remove the sutures. They are also required to be followed-up till twelve months for refractive error correction. So it is possible then that if the study was extended up to one year, the cost of ECCE might increase and may be higher than PEA technique.

Another limitation is some costs that were not included in this study. For example, the cost of training the ophthalmologist in handling the PEA equipment and the cost of patient's productivity loss, after being discharged from the ward. Training cost is considered direct cost for the hospital in the total cost of cataract surgery. 
In conclusion, in the limitations mentioned earlier, ECCE technique is more cost-effective compared to PEA. Cost of equipment and low frequency of the PEA technique done in HUKM are the two main reasons for the high unit cost of PEA compared to ECCE. However in the long term, it is likely that PEA cost will be less compared to ECCE and may alter the final result of cost-effectiveness analysis.

\section{Acknowledgements}

We would like to acknowledge Dr. Zainal, Dr Azman, Suzainah, and the contributions of the staff of Hospital Universiti Kebangsaan Malaysia directly or indirectly in this study. This study was funded by the Intensification of Research in Priority Areas (IRPA) Project No. 06-02-02-0106, grant from the Ministry of Science, Technology and Innovation, Malaysia. Lastly, we thank Dr. Bastaman Basuki for reviewing early drafts.

\section{REFERENCES}

1. Limburg H, Foster A, Vaidyanathain K, Murthy GVS. Monitoring visual outcome of cataract surgery in India. Bull World Health Organ. 1999; 77:455-60.

2. Resnikoff S, Pascolini D, Etya'ale D, et al. Global data on visual impairment in the year 2002. Bull World Health Organ. 2004: 82:844-51.

3. Minassian DC. Rosen P. Dart JKG, Reidy A, Desai P, Sidhu M. Extracapsular cataract extraction compared with small incision surgery by phacoemulsification: a randomized trial. British Journai of Ophthalmology. 2001;85:822-9.

4. Rizal AM, Aljunid SM, Harom AF, et al. Cost analysis of cataract surgery with intraocular lens implantation: a single blind randomized clinical trial comparing extracapsular cataract extraction and phacoemulsification. Med J Malaysia. 2003; 58:380-6.
5. Watson A, Sunderraj P. Comparison of small-incision phacoemulsification with standard extracapsuiar cataract surgery: Post-operative astigmatism and visual recovery. Eye. 1992; 6: 626-9.

6. Imaizumi M, Takaki Y, Yamashita H. Phacoemulsification and intraocular lens implantation for acute angle closure not treated or previously treated by laser iridotony. I Cataract Refract Surg. 2006:32:85-90.

7. Sneiingen T, Evans JR, Ravilla T, Foster A. Surgical interventions for age-related cataract (Cochrane Review). The Cochrane Database of Systematic Reviews. 2002: Issue 2.

8. Asbell PA, Dualan I, Mindel J, Brocks D. Ahmad M. Epstein S. Age-related cataract. Lancet. 2005;365(94,79): $599-609$

9. Steinberg EP, Tielsch JM, Schein OD, et al. The VF-14: An index of visual functional impairment in patients with cataract. Arch Ophthalmol. 1994;112:630-8.

10. Cassard SD, Patrick DL, Damiano AM, et al. Reproducibility and responsiveness of the VF-14: An index of visual functional impairment in patients with cataracts. Arch Ophthalmol. 1995; 113: 1508-13.

11. Asimakis P, Coster DJ, Lewis DJ. Cost-effectiveness of cataract surgery: A comparison of conventional extracapsular surgery and phacoemulsification at Flinders Medical Centre. Aust N Z J Ophthalmology 1996; 24: 319-25.

12. Steinberg EP, Tielsch IM, Schein OD, et al. National study of cataract surgery outcomes: Variation in 4 month postoperative outcomes as reflected in multiple outcome measures. Ophthalmology. 1994;101:1131-41.

13. Loo CY, Kandiah M, Arumugam G, et al. Cost efficiency and cost-effeciveness of cataract surgery at the Malaysian Ministry of Health Ophthalmic Services, Intem. Ophthalmology. 2004;25:81-7.

14. Lundstrom M, Brege KG, Floren I, Roos P, Stenevi U, Thorburn W. Cataract surgery and effectiveness: Variation in costs between different providers of cataract surgery. Acta Ophthalmol Scand. 2000;78:335-9.

15. Espallargues $M$, Alonso J, The Barcelona I-PORT Investigators. Effectiveness of cataract surgery in Barcelona, Spain: Site results of an international study. J Clin Epidemiol. 1998;51: 843-52. 